\title{
VIRTOPSY-Penetrating head trauma caused by a shovel handle: A case presentation
}

\section{VİRTOPSİ-Bir kürek sapının neden olduğu penetran kafa travması: Olgu sunumu}

\author{
Erdal Özer*, Ali Yıldırım, Özgür Enginyurt
}

Department of Forensic Medicine (Assist. Prof. E. Özer, MD, Assist. Prof. A. Yıldırım, MD), Gaziosmanpaşa University School of Medicine, TR-60150 Tokat, Department of Family Medicine (Assist. Prof. Ö. Enginyurt), Ordu University Teaching and Research Hospital, TR-52200 Ordu

\begin{abstract}
The term virtopsy was coined from the words 'virtual', and ' autopsy' derived from their Medieval Latin 'virtualis' and ancient Greek 'autopsia' terms, respectively. In electronics, and computer sciences, virtual is defined as 'an adjective of or relating to a computer technique by which a person has the experience of being in an environment created by the computer, and of interacting with and causing changes in it. Autopsia is a combined form of autos, and opsis which means examination of body surface and of three body cavities of a cadaver to find the evidence of death or confirm the cause of death. Virtopsy is a procedure of virtual autopsy performed by using modern medical imaging, and assessment technologies. Penetrating head traumas by a foreign body is rarely seen, apart from those caused by gun pellets directed at head. Penetrating skull wounds, generally of transorbital type caused by nails, screws, paint brush have been reported .Our case has been found to be worthy of presentation in that any similar type of penetrating wound has not been encountered after our literature screening, and its cause of death was revealed by virtopsy.
\end{abstract}

Keywords: Autopsy, virtopsy, head trauma, cause of death, forensic medicine

\section{Özet}

Virtopsi Ortaçağ'da Latince bir terim olan 'virtual' ve antik Yunanca'da kullanılan 'otopsi 'teriminin birleşiminden oluşmuştur. Elektronik ve bilgisayar bilimlerinde ise virtual terimi bir bilgisayar tekniği ile ilişkiyi ya da onun sıfatını tanımlamakta olup, bilgisayar tarafından oluşturulan bir ortamda kişinin bulunması, onunla etkileşime geçip, üzerinde değişiklikler yapmasıdır. Otopsi, otos ve opsis terimlerinin birleşimi olup kadavranın vücut yüzeyi ile üç vücut boşluğunun ölüm bulguları ve ölümün nedeninin doğrulanması açısından incelenmesidir. Virtopsi ise sanal otopsi olup modern medikal görüntüleme ve değerlendirme teknolojilerinin kullanıldığ bir işlemdir. Eski Kafa bölgesine yönelmiş ateşli silah mermi çekirdeği-saçma tanesi dışında kafayı penetre eden yabancı cisim yaralanmaları nadir olarak görülmektedir. Bildirilen olgular ise çivi vida resim firçası gibi maddelerin kafayı penetre edebildiği genellikle de bu yaralanmaların transorbital yaralanmalar olduğu bildirilmektedir. Olgumuz da yapılan literatür taramasında benzeri bir penetran yaralanma tespit edilmemesi ve virtopsi sonucu ölüm sebebi tespit edilmesi açısından sunulmaya değerli bulunmuştur.

Anahtar sözcükler: Otopsi, virtopsi, kafa travması, ölüm nedeni, adli tıp

Geliş tarihi/Received: March 28, 2012; Kabul tarihi/Accepted: April 24, 2012

\section{*Corresponding author:}

Dr. Erdal Özer, Adli Tıp Anabilim Dalı, Gaziosmanpaşa Üniversitesi Tıp Fakültesi, TR-60150 Tokat. E-mail: er4077@yahoo.com

This case report presented as a poster at the $8^{\text {th }}$ Anatolian Forensic Sciences Congress in Burdur 


\section{Introduction}

The main objective of forensic medicine is to describe, analyse, document, and submit medical findings of forensic value detected in living, and deceased individuals in understandable format to the court [1]. The term autopsy means seeing with one's own eyes. Autopsy is a scientific investigation in order to reveal pathologic and traumatic changes, to detect the cause, mechanism, and origin of death, and to establish a relation of causality in forensic cases [2]. Autopsy is the examination of all body surface, and body cavities, and (if needed) samples obtained from the sites of investigation. The term 'virtopsy' coined by combination of terms 'virtual', and 'autopsy' is described as a procedure of autopsy is carried out under the guidance of computerized medical, and imaging technologies with out any surgical exploration [3, 4]. Virtopsy or virtual autopsy was developed by Richard Dirnhofer [1], and it is still evolving recently by investigations performed by Michel Thali et al. [5]. Thali [5] reported that autopsy deforms 3D geometric configuration of the body, and identical findings could be obtained noninvasively by imaging techniques.

Our aim is to demonstrate that definite cause of death can be identified in some cases by virtopsy without any need for classical autopsy.

\section{Case report}

Our case is deemed as an interesting forensic case in that the victim was exposed to penetrating head trauma caused by a foreign object not cited in the literature so far, and in addition his cause of death could be determined by virtopsy. Our case was a 37-year old, $175-\mathrm{cm}$ tall male patient weighing $85 \mathrm{~kg}$ who had been exposed to penetrating head injury caused by a shovel handle in his workplace (Figure 1 and 2). The physical examination of our intubated patient who was referred to our hospital revealed a closed conscious, and a Glasgow coma scale score of 3 (GKS-3). He was refractory to painful stimuli without any evidence of spontaneous respiration. A part of the shovel handle was found to be penetrated from the right maxillary region, passing below the orbita, and edge of the nasal cartilage. It was palpated under the right side of the parietal scalp. Bilateral perorbital diffuse hematoma, and edema were also detected. His computerized tomography (CT) scan disclosed signs of penetrating head trauma on intracranial, right frontotemporoparietal region, diffuse contusio cerebri, traumatic subarachnoidal bleeding $(\mathrm{SAB})$, fragmented fracture on the anterior wall of the right maxillary sinus, and hyperintense fluid densities consistent with bleeding, and a $7 \mathrm{~mm}$ midline shift effect to the left were detected (Figure 3 and 4). As a result of physical examination, and radiological scannings, the cause of death was detected to be cerebral bleeding due to bone fractures, and also diffuse cerebral tissue damage developed secondary to a penetrating injury caused by a shovel handle (Figure 2).

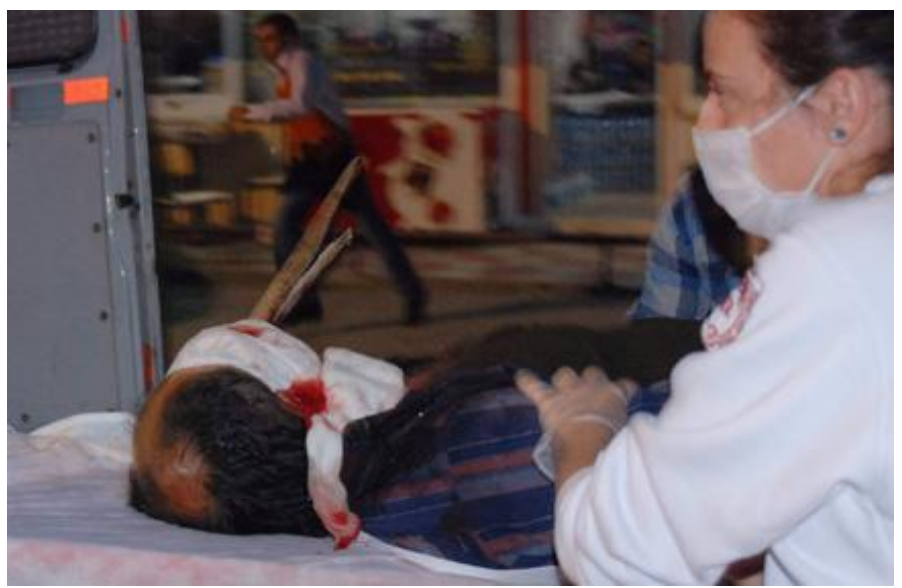

Figure 1. Patient with penetrating head injury caused by a shovel handle transported on an ambulance stretcher. 


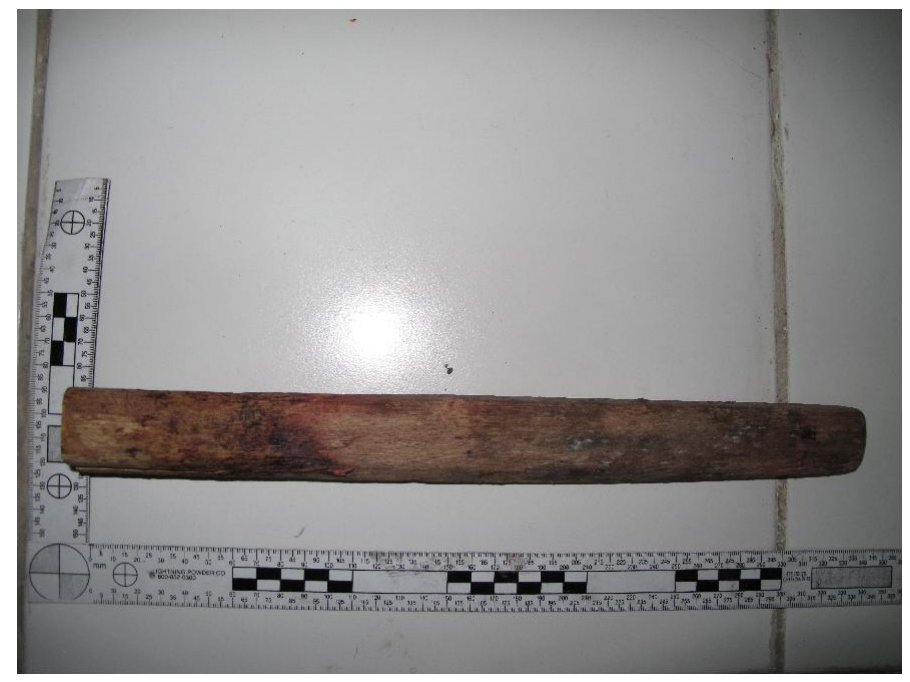

Figure 2. Shovel handle detected as a cause penetrating head injury.

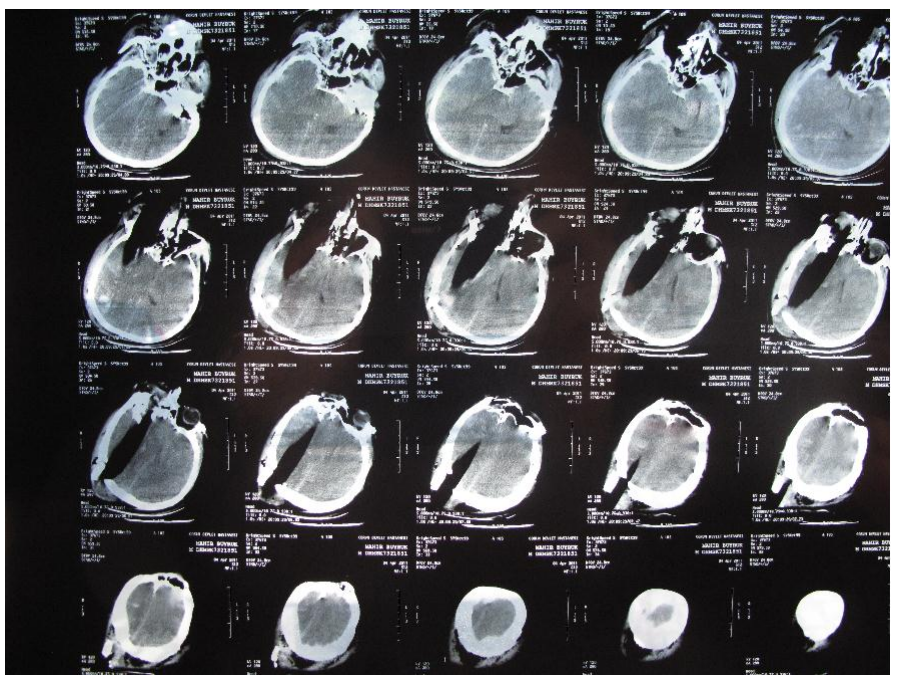

Figure 3. CT image of the penetrating head injury.

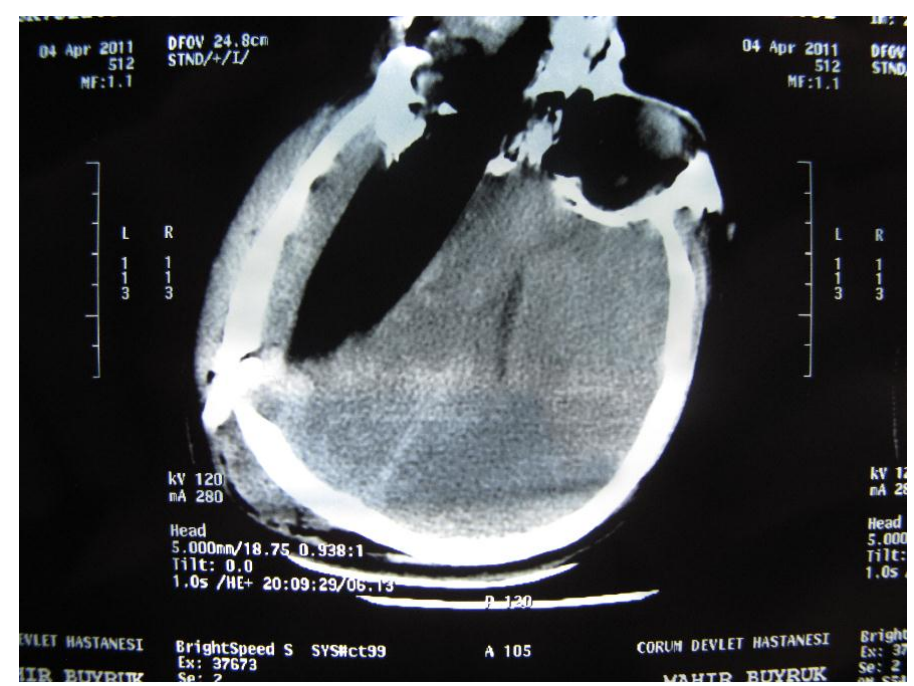

Figure 4. CT image demonstrating the culprit foreign object. 


\section{Discussion}

Primary usage of radiologic techniques for forensic causes goes back to the discovery of $\mathrm{X}$-rays [3]. Although authors like Brogdon, and Vogel indicated the beneficial use of radiology in forensic medicine, rapid advancements in modern medicine seem to be overlooked by forensic medicine. It has been reported that for ages radiologic means have not taken place in the routine of forensic medicine [6-8]. In 1895, Wilhelm Conrad Roentgen demonstrated the first x-ray image, and in the same year he submitted to the court image of the bullet in the leg of a patient wounded by a firearm which could not be found by a surgeon [6]. Though plain x-ray is the most frequently used technique in autopsy, it has been known as an auxillary technique not taking place of an autopsy, but contributing to the accuracy of autopsy [2]. Some studies have also indicated that ultrasonographic scans can be used in forensic autopsy, and clinical forensic medicine [9]. Besides, some reports have asserted that contrast-enhanced angiography could detect vascular changes during autopsy [10]. Thali et al. [5] who started virtopsy project in the year 2000, in Bern University, Switzerland, reported that with time magnetic resonance (MR) microscopy could take place of postmortem histologic examination. In a study by Thali et al. [5] the authors indicated that using CT scans they could detect bullet entry/exit holes in the head after firearm injuries and MR imaging (MRI) is useful in the determination of the bullet projectile, and soft tissue wounds by virtopsy approach. In a study performed by Plattnerr et al. [11] in cases of death caused by diving injuries, using multi-slice CT and MRI could detect pulmonary barotrauma, and fatal gas embolism as causes of death. In another study by Emin Aghayev et al. [12] the authors reported that they could identify cause of death as cerebellar herniation in 3 cases with blind head trauma using multi-slice CT and MRI. Physical examination of our case detected a part of the shovel handle was found to be penetrated from the right maxillary region, passing below the orbita, and edge of the nasal cartilage. It was palpated under the right side of the parietal scalp. CT scans detected cerebral bleeding due to bone fractures, and also diffuse cerebral tissue damage which developed secondary to a penetrating injury caused by a shovel handle. Since a consensus was formed about definite cause of death, as a result of physical, and radiologic examination of our case, autopsy procedure was terminated using virtopsy approach without resorting to classical autopsy. As advantages of virtopsy over classical autopsy, are examination of the wounds without distorting body architecture, and any risk of infection, rapid delivery of the decedents to the relatives/intimates after radiological investigations, and its more acceptable nature by decedent's intimates. While among disadvantages of virtopsy, availability of only inadequate number of comparative data, and inability to identify all possible pathologic changes, and also any clues in favour of infection, lack of any discriminative attribute distinguishing between ante- and post-mortem traumas, and failure to detect post- mortem artefacts, and discolorations can be enumerated [4].

In conclusion, scene of the accident should be investigated thoroughly in cases of death secondary to these very rarely seen injuries encountered in literature reviews, medical records, ante-, and post-mortem radiologic images should be procured, and analyzed in detail. Besides, information should be inquired from the eyewitnesses about the occurrence of the event, and if needed, consultation should be required from the relevant specialist. Although exploration of three body cavities is enforced by the law, implementing all of these above-mentioned procedures, definite cause of death can be determined without any need for surgical exploration. With presentation of this case report, owing to nonexistence of any similar forensic case in the literature, we aimed to evaluate the advantages and the disadvantages of determining the cause of death using imaging modalities, and discuss applicability of virtopsy in Turkey. 


\section{References}

1. Dirnhofer R, Jackowski C, Vock P, Potter K, Thali MJ. Virtopsy: minimally invasive, imaging-guided virtual autopsy. Radiographics 2006; 26: 1305-33.

2. Soysal Z, Eke SM, Çağdır AS. Adli Otopsilerde Yapılan Radyolojik İncelemeler. In: Soysal Z, Eke SM, Çağdır AS (Eds). Adli Otopsi, Cilt 2, İ.Ü. Cerrahpaşa Tıp Fakültesi Yayınları 1999; pp 512.

3. Çelik M. Virtopside çok kesitli bilgisayarlı tomografinin önemi. Uzmanlık tezi. Sivas-Turkey 2008.

4. Patowary AJ. Virtopsy: One step forward in the field of forensic medicine. J Indian Acad Med 2008; 30: 32-6.

5. Thali MJ, Jackowski C, Oesterhelweg L, Ross SG, Dirnhofer R. VIRTOPSY - the Swiss virtual autopsy approach. Leg Med (Tokyo) 2007; 9: 100-4.

6. Brogdon BG. Radiological identification of individual remains. In Forensic Radiology, Brogdon BG, ed. 1998; pp: 149-87.

7. Grabherr S, Stephan BA, Buck U, Näther S, Christe A, Oesterhelweg L, Ross S, Dirnhofer R, Thali MJ. Virtopsy? Radiology in Forensic Medicine. Imaging Decisions MRI 2007; 11: 2-9.

8. O'Donnell C, Rotman A, Collett S, Woodford N. Current status of routine postmortem CT in Melbourne, Australia. Forensic Sci Med Pathol 2007; 3: 226-32.

9. Uchigasaki S. An experimental study of application of ultrasonic imaging to forensic medicine (The First Report). Res Pract Forensic Med 2001; 44: 89-93.

10. Grabherr S, Djonov V, Yen K, Thali MJ, Dirnhofer R. Postmortem angiography: review of former and current methods. Am J Roentgenol 2007; 188: 832-8.

11. Plattner T, Thali MJ, Yen K, Sonnenschein M, Stoupis C, Vock P, ZwygartBrügger K, Kilchör T, Dirnhofer R. Virtopsy-postmortem multislice computed tomography (MSCT) and magnetic resonance imaging (MRI) in a fatal scuba diving incident. J Forensic Sci 2003; 48: 1347-55.

12. Aghayev E, Yen K, Sonnenschein M, Ozdoba C, Thali M, Jackowski C, Dirnhofer R. Virtopsy post-mortem multi-slice computed tomography (MSCT) and magnetic resonance imaging (MRI) demonstrating descending tonsillar herniation: comparison to clinical studies. Neuroradiology 2004; 46: 559-64. 